\title{
Moral Courage of Students Qualifying to Teach in Special
}

\author{
Education \\ Shachar Nitza ${ }^{1} \&$ Baratz Lea ${ }^{1 *}$ \\ ${ }^{1}$ Achva Academic College, Shikmim, 79800, Israel \\ *Baratz Lea, E-mail: lbaratz@netvision.net.il
}

It is curious that physical courage should be so common in the world and moral courage so rare.

Mark Twain

\begin{abstract}
A large body of research has discussed the issue of moral courage, but there is a lack of research on students who are qualifying to teach in special education. Moral courage is considered as the bridge between talking about values and actually implementing them. Ten special education students in their last year of studies in a large college in Israel participated in the research. Most of the student teachers chose special education for personal or family-related reasons. Data were collected with qualitative research tools: portfolios, field diaries, and partially-structured interviews and analyzed by qualitative research methods, identifying in the students' stories themes, which were divided into categories. Two kinds of courage were described; courage as a part of the teaching process, when the students independently decided to teach differently from how they were expected to teach, and courage in an exceptional act in which they intervened for the sake of one single child. In every case the students were aware of the fact that they risked their professional future, their "good name" and their studies in the college. Several motives were identified for their behavior: ideological motives, altruism and caring, moral inner motive and responsibility for others, personal reasons that were connected to their own past history, and the existence of support from college instructors.
\end{abstract}

\section{Keywords}

moral courage, students, special education

\section{Moral Courage}

Facing ethical issues often obliges us to do something that requires acting in the face of inconvenience, harm or danger. Such actions require "moral courage" (Duska, 2013). Rorty (1988), discussing the psychology of morality, puts the issue sharply into focus and explains the need to re-conceptualize courage. She addresses courage as part of her attempt to understand various human virtues and differentiates between the traditional definition of courage and a new definition of courage. According to her, the traditional conceptualization of courage raises various problems concerning its very 
definition of being a virtue. Virtue is defined as something of high moral standards or a positive trait to be morally good and thus is valued as a foundation of principle and good moral being (Schechter \& Iram, 2002). Rorty (1988) believes that there is a need to re-define the question, "What is courage?" Her starting point is the traditional definition of courage as a set of dispositions for overcoming fear of obstacles and performing difficult and dangerous actions. According to her, this definition does not present courage as a virtue, even if it is an important quality from the point of view of survival. She maintains that in order to retain the view of courage as a virtue, the cognitive setting should be redefined and placed within a new setting, that embeds previously defined qualities, such that courageous thoughts or actions would not contradict or threaten other human virtues. According to some definitions, moral courage is the ability of individuals to overcome fear and stand up for their main values and ethical commitments (Lachman, 2007), or as Kidder formulates it, "moral courage is the courage to be moral" (Kidder, 2005, p. 10). According to Kidder (2005), moral courage includes three main elements: danger, principles and endurance, and it can be identified by five basic qualities: integrity, honor, responsibility, decency, and compassion. Thus, moral courage is the bridge between talking about values and actually implementing them.

Miller (2000) defines moral courage as the willingness to take a stand in defense of principles or convictions even when others do not. People who exhibit moral courage are often subject to a number of risks associated with taking a stand, including inconvenience, unpopularity, ostracism, disapproval, derision, and even harm to themselves or their relatives. Accordingly, teachers' very perception of moral education as a central aspect of their work is, in and of itself, an expression of moral courage (Klaassen \& Maslovaty, 2010). As Klassen claims, moral courage among teachers entails a mental challenge. Individuals who take this stance risk damaging their reputation, their emotional world, integrity, or self-image (Klaassen, 2007). It is less difficult to promote or encourage teachers to exhibit morally courageous behavior when the school is not subject to the control of a political authority. The concept of the "price" is expressed in the teachers' world when they must take into consideration that they may have to pay the consequences for their actions (Baratz, Reingold, \& Abuhatzira, 2013). This kind of thinking matches student's perception about their acting in class. Moral courage is not only connected to a choice between right and wrong, but also to dilemmas that force us to choose between two right things (between two core values), and even to choose the lesser of two evils. The choice between one right thing and another is more difficult than choosing between right and wrong. Lachman (2007) discusses the internal conflict between two obligations of nurses, both defined in their ethical code. Morally courageous nurses are willing to perform moral acts even when they know they will have to pay a considerable personal price for it, thereby placing their ethical obligations and core values in the forefront.

Aultman (2008) concludes that discourse with colleagues about experiences relating to ethical dilemmas is an important starting point from which to find solutions to such dilemmas. Discourse among professionals from the same field, but from different locations (such as doctors from country 
areas and urban areas) can promote an understanding of political, emotional and ethical factors, "and by that intensify moral courage and ethical activity" (p. 67).

\section{The Pre-Service Special Education Students}

Choosing teaching in special education almost totally stems from intrinsic motivating factors (Tangala \& Margaret, 2007). The attributes characteristic of the special education teacher as described in research literature are: great commitment, creativity, flexibility, steadfastness in face of the unexpected, patience, tolerance, sensitivity, and empathy towards others and desire to give, readiness to see work as a challenge and goal, ability and readiness to invest physical, intellectual and emotional effort in hard and complex work (Aboudi \& Dangur, 1992).

The motivation of students who choose special education as the preference subject of their studiesis mentioned in Hillel-Lavian $(2008,2013)$. The majority hold a rather personal approach to special education, due to personal and family difficulties; the factor of individual or family differences (siblings or parents) was the strongest and most prevalent finding. This factor emerged in the personal histories of most of the participants as a motivating factor in choosing special education. Some had learning disability, some were new immigrants, some sisters to siblings with special needs, which gave them, early in life, successful experience with care, whether in volunteer work, school or in the army. Some of the participants commented on the influence of certain special teachers who were role models for them (Hillel-Lavian, 2008). Gavish and Friedman (2001) believe that special education teachers made a conscious decision, which fell into place during the course of their lives, to dedicate themselves to emotionally demanding work that involves giving daily assistance to society's weakest and most vulnerable. But the most ideological reason seems to be as Hillel-Lavian (2013) noted: "Seeing Special Education as More Meaningful than Regular Education” (p. 22).

Hanline (2010) posited that pre-service special education teachers recognize how different instructional practices influence student learning, particularly when the pre-service teacher is able to work one-on-one with a student. The need to train teachers according to updated curricula, revised once the educational needs of both the teacher trainees and their pupils, has been understood (Iannacci \& Graham, 2013). Further, pre-service special education teachers indicated that their practical experiences (e.g., working with a host teacher in a school setting) provided them with opportunities to see the implementation of best practice, thus allowing them to make connections between coursework and practice (Hanline, 2010).

Our research points to pre- service special education students recognizing situations in which they act in accordance with their ethical and moral positions, even though they are in conflict with the situation in which they were involved. 


\section{Methodology}

Our research question: What characterizes moral courage in the qualification of teachers in special education, and from where does it derive? In order to answer this question we chose the interpretative qualitative perspective. This is particularly suitable in cases where one tries to understand a phenomenon and reveal factors and motives that were not considered so important at the outset, and which in retrospect are likely to be revealed as central from the standpoint of the participants in the research and of the researchers (Tzabar \& Ben-Yehoshua, 2001). Ten pre-service special education students who were doing their practical training in kindergartens and in public schools were chosen on the basis of the researchers' professional acquaintance with them. Each one had taken some form of action that was noticeable or outstanding in their fieldwork.

\section{The Research Tools}

Data were collected from several sources in order to keep triangulated results and increase validity (Zellermayer, 2001): a portfolio that students were writing during their work, end of year summary projects, partially- structured interviews and a field-diary of one of the researchers. At first we chose from the students' portfolios those which contained stories including different or special attitudes which we can define as moral courage. In the second stage they were interviewed in partiallystructured interviews (Shkedi, 2003). The participants selected the location for the interview, making sure that it was suitable and free of distractions. They were asked to describe a personal experience or incident, which they believed included an aspect of moral courage in their field or in the classes. The interviews consisted of a qualitative, "self-defined narrative", in which the interviewees described a specific incident in their life story (Spektor-Marsel, 2011), which they viewed as a demonstration of courageous behavior in the course of the teaching process. We also asked them what their motivation to behave in this way was. Data collected were recorded, in order to ensure their precision and entirety. The first stage of the inductive analysis included revelatory reading of the content by each one of the researchers separately, in an attempt to find characteristics of courageous acts. Then we reread the interview scripts together a number of times in order to identify and focus on recurring themes (Shkedi, 2003). We used a strategy of continuous comparison (Guba \& Lincoln, 1981) in identifying within the stories situations of conflict and dilemma, where the interviewees knew that they were expected to act in a certain way but instead acted in another. During this stage, all the data were read in sequence, to obtain a broad and general sense of the connections between the various concepts and motifs embedded in the data (Shkedi, 2005). Then we analysed each story according to these themes, which we divided into categories. 


\section{Ethics in Research}

Throughout the research, emphasis on the rights of the participants was meticulously observed, for the purpose of upholding professional ethical standards and to avoid invading the privacy of the individual participants. As a first step in upholding ethical standards, the purpose of the research and the framework in which it would be carried out was made clear to the participants, as well as the fact that their participation in the research was completely voluntary. As mentioned, the interviews were recorded and transcribed, and the participants were allowed to read the transcripts, to ensure that their words had been faithfully transcribed. Personal details of the participants have been suppressed or changed to prevent the possibility of identification.

\section{Findings}

In the stories by the study participants, students and special education interns we identified a common narrative pattern: an act that can be defined as moral courage during the teaching process was openly described together with the distress-causing situations of conflict and dilemma that preceded it. The conflict was caused due to awareness that they are expected to act in a certain way, yet they chose a different one. Their stories were reviewed by a system of categories that included: classification of the acts and their results, risk and cost, and motives.

\section{Acts and Results}

We have identified two situations in which the participants exhibited courage: courage as part of the teaching process and courage in an exceptional act:

1) Courage as part of teaching - the students consciously took a different stand and teaching approach from the teachers in the experimental class, out of recognition that the teachers were not doing their jobs properly.

The students assessed (based on the special education teaching principles they acquired during training) that the teachers underestimate the abilities of the children, lower their expectations of them and do not attempt to reach the full potential of the special education pupils under their care. Therefore, the students independently decided what to teach, based on their own discretion:

Adi, who teaches in a kindergarten, says: "I noticed there was scarce use of high order thinking terms, which is different from what I learned about Vygotsky's learning principles... I chose to teach a science topic using a research and discovery method that contains scientific terminology..."

Marina, who taught a $9^{\text {th }}$ grade learning disability class, noticed the pupils are insecure and lack basic learning skills. Contrary to the teacher's request she decided to teach the pupils how to learn independently using the internet, the library and graphic organizers. According to her: "The goal was to develop a literate learner who can approach information sources on his own. I created an enabling learning environment so they may realize the source of information is not only the adult or the teacher; they can obtain it independently from various sources". 
Yalata decided to teach three autistic children in a group, as opposed to the request of the kindergarten teacher to work only with one child. She believed that children with communication difficulties should work on their communication skills with their friends during learning.

All three students felt uncomfortable with the attitude of the teacher that lowered the pupils' potential, and so they acted against expectations. Adi was supported and appreciated by the kindergarten teacher (Shachar, 2015), while Marina and Ya'ara received negative and oppositional reactions.

2) Courage in an exceptional act — in these cases we identified conscious endurance, or steadfastness, in the interviewees. In all cases the act involved intervention for a single child. Sometimes it was a onetime act and other times it was an ongoing one.

Zohar noticed a pupil who exhibited unusual behavior during an experiment which involved hot water. The pupil ran to the other side of the class, withdrew into himself and seemed to be in distress. The pupil is unpopular among the other pupils and the teachers. Zoher notes: "I couldn't take my eyes off him. It bothered me! It was hard for me to continue the class. I shortened it in order to hear what stressed out the kid. Everyone went outside on a break and the boy remained in class. A bell went off inside me...something was not right...But who can I turn to in the school when I'm just a student?"

Zohar tried in vain to attract the attention of the education staff to the boy. But they all turned her down, except for a drama therapist, who had also refused at first. It was eventually found that the father of the child was abusing him, pouring hot water on his hands as punishment. Following Zohar's intervention, the kid was removed from his home two weeks later.

Shira and Adva confronted a school principal who was about to expel a pupil to cultivate school excellence. Shira was requested before a teachers' meeting to amplify the pupil's problems so it may be easier to expel him. According to her statement: I decided to stand my ground despite the definitive demand. I described or's good sides objectively...The principal looked at me with surprise... The rest of the teachers followed my lead despite their fear of the principal.

Adva took an even bigger risk when during her internship year she defended a pupil in her class, who was a new immigrant and had difficulty speaking and reading, against the principal and school therapist. At first, they requested her to remove him from the class during meal time because "he disgusts everyone", and make him sit at the back of the classroom. Adva says: "During staff meetings all the teachers reported that the kid does not communicate or show advancement. I said he was advancing, speaking and playing with the other kids and that he learned to read and write". As a result the principal called me into her office and yelled at me that she will not allow me to give the mother an incorrect assessment on the boy. I got up and raised my voice as well telling her she had crossed the line.

The result was that Avda gave the mother the power to oppose the principal's decision to remove him from school.

Yaniv fought with the teacher of an unpopular pupil whom she decided should sit during class behind a screen that separates him from the class, so that he will not disturb other pupils. At first Yaniv reacted 
emotionally: "A kid sitting behind a curtain! I was horrified! He was separated and prevented from interacting with the other pupils. I tried to convince the teacher to remove the screen and she claimed I was still young and do not understand anything regarding education! I argued and during one of the classes I stood up and physically removed the screen outside. Eventually, I told her you do whatever you want in your classes and stay out of mine"! Simultaneously Yaniv created trust between himself and the pupil, and as a result: He blossomed! "And improved in other subjects as well".

Yaniv by passed the hierarchy of the school, and reported to the instructors at his college. As a result, when the year ended, a letter was sent to the school principal reporting the incident.

Shiri taught a class of pupils with symptoms of mental disability, and noticed a clever boy who was above the level of the class - the class teacher believed so as well-but whowas being kept in this school by the principal due to reasons of administration and budget. Shiri, much like Yaniv, acted in several stages. First, she challenged the pupil to make sure he was above the class level. Afterwards, through long conversations, she tried to convince the class teacher to report this to the mother and convince her to pull out the pupil from this class and this school. The teacher refused in tears. Shiri's struggle to decide on her next move was similar to that of the teacher's: "I realized that the teacher suffered from having the pupil in this class. When I talked with her she avoided giving me clear answers. I told her I know the real reason...She said such action on her behalf might lead to "a disaster" in her career, and she feels no motivation to change the situation". Eventually, Shiri convinced the teacher to meet the mother without informing the principal, and as a result the mother asked a special committee to remove the pupil and place him in a different school.

Mor taught in a kindergarten with pupils suffering from mental disability and Down Syndrome, in which the kindergarten teacher gave up on trying to advance the pupils on the educational and social levels. At first, Mor commented to the kindergarten teacher regarding her low level of teaching and that the pupils do not learn any new material. As a result she received hostile treatment from the teacher and the kindergarten staff. Afterwards she reported to her instructor at the college that a pupil was tied to a chair to prevent him from moving around the kindergarten and disturbing the pupils and the teachers: " $I$ faced a dilemma, should I say something or not... I felt helpless... this is even worse, because I involved someone from the outside when I told you...But you helped me. You told the kindergarten teacher that if she continued tying down the kid, you will take it to the Ministry of Education and the press".

The stories of the students show actions that exceed their authority: the act was accompanied by a dilemma and an emotional response: some of the acts were directed at a forum of an entire class and some regarded saving only one pupil: these acts were done not only in interaction with the teacher or kindergarten teacher but were also directed against the policy of the principal or the education system. 


\section{The Risk and the Cost}

According to Kidder (2005) one of the characteristics of moral courage is risk: it was this that stood out in the stories of the interviewees alongside the cost of their actions. First, the study participant's actions involved an emotional and "price tag". The conflict whether to act or not influenced them emotionally. For example there were sentences such as: "I choked: I went outside to the corridor and started crying bitterly" or "I went home and fell apart; it affected my life"; or "I was scared: even three months later I said something to colleagues in college and made them swear that no one should know about it"; or "At first I was shocked! What was she expecting me to do! Lie?" A particularly difficult sentence was: "My year was a living hell!"

Sometimes the price was a social one, like Mor who commented to the kindergarten teacher and eventually informed people outside the kindergarten: "The staff wouldn't talk to me anymore, only made faces at me. I felt like an outsider. It is not a nice feeling to come to the kindergarten when no one would talk to you". Or Edna for instance who said: “The teacher didn't speak to me for 4 months. It was a nightmare. I was alone. Like on a desert island, my colleagues refused to help me and the person I needed was not there".

The intern teachers' feared receiving a negative assessment from the training teachers, which would cause difficulties once they entered the education system. However, the fear was also part of the internship itself, as Adva noted: "I thought she would send me home then and there".

The students also expressed other various types of concern. For example:

Yaniv: "This is my third year: I was afraid she would damage my studies, my degree. She could have given me bad feedback and make my life miserable at the same time".

Marina: "She is the teacher and I am the student. She has authority over the pupils. She could have failed me during classes with a sentence or a look. I was afraid this would affect my end of the year grade".

Shiri: "I was putting my profession on the line. That is why it took me so long to decide whether to say anything: I wanted to finish my degree peacefully and quietly".

The professional risk is also a long term one:

Shiri: "I jeopardized the principal's trust in me. If she were to find out, she wouldn't want me as part of her school".

Marina: "This will be a mark against my name in the system when I try to get work".

Mor: "I knew I was out of line and that it could backfire on me in so many ways, whether in my reputation or in finding work where I live".

The interviewees did in fact understand that what they were doing was outside their authority or the environment's expectations of them; it might take not only an immediate social and emotional toll, but also risk their professional future at the very beginning of their career and even before entering the national education system. Any feedback from a more experienced teacher is significant.

If all this is true, then why did they act?

Published by SCHOLINK INC. 


\section{The Motive}

The interviewees mentioned several motives, some related to another person and some related just to themselves. Occasionally the two would combine:

\subsection{Altruism and Caring}

Some of the study participants mentioned motives related to another person, who was always the pupil.Zohar says: "I managed to save a kid! And as small as I might be in the system, I can make a difference". Mor adds: "These kids have no voice of their own! No one gives them a chance!! And even if I won't reach the highest summits, I might be able to move some mountains". Shiri said: "It was the kid! Seeing the kid in his natural place where he belonged where he should be. It is unjust and inhuman to place a bright boy in a mental class". Or Edna: "There is a dilemma-whether to keep quiet in favor of personal gain or fight for the children?". And finally Adva: "It is true that even today I fight for the children and find myself in disagreements with the other teachers".

\subsection{Ideological Motives}

Students who major in education from their ideology in the course of their studies. This was reflected byYaniv: "Wrong — doing and injustice push me much more than fear does: to make something right which was wrong-this is our biggest job. It stems from my belief". Marina adds: "Kids with learning disabilities experienced failures, low self-esteem and low social image. Teachers have the power to affect a person's self-image and it is the teacher's calling".

\subsection{Moral Inner Motive}

A moral motive does not take regard of status, benefits, damage or self-loss. People who are driven by an inner truth sense they must act no matter the risk-cost consequences.

Adva: "I told her, experience is not necessary to distinguish between moral and immoral". Shiri: "It is morality, it is a part of my values, my innermost place...the teacher's heavy moral dilemma can also be seen. On one side there is the pupil and on the other her entire career". Yaniv: "Justice is imperative". Edna: "This is the price I had to pay for justice and I took the risk: something inside me told me I should stand for what I believe in".

\subsection{Personal Motive}

One can detect in the students stories' an interrelation between personal involvement and personal history. Mor: "It comes from my childhood: when I was younger, school was difficult and I had no one to support me, to tell me I can make it". Or as Yaniv says: "As a teenager I had difficulties and I had no one to guide me. This is the main reason I became a teacher". Marina: "It is my temperament: I was told 'you are opinionated. I was mad and decided to show that being opinionated is a good thing"! There were also family related motives. Shiri: "I thought of the pupil as if he were my son". Zohar: "Everything comes from home. Throughout the conversation I hear my mom's voice in the back of my head". To some of the students this was a corrective experience to be able to provide support to the pupils, something they themselves did not receive in childhood. 


\subsection{Support from College}

The most interesting finding was that what enabled them to act was the support they received from the college as an institution and from their instructors in particular. They did not feel alone. The support began at the emotional level and proceeded to an ideological and practical one.

Edna: "It is a combination of my character and the principles I was taught in college-Freire's theory that speaks of the oppressed in society". Adva: "I knew I had the college's support. They promised me: don't worry! We will make sure you will pass this". Mor: "I did not know what to do, I turned to you". Marina: "Once you made me feel confident, I was able to act without fear". Shiri: "I knew you would not be angry. If you found out you might even pat me on the back. And you would have done the same".

\section{Discussion and Conclusions}

Despite the careful approach we need to take when drawing conclusions from a qualitative study that is based on a small number of interviewees, the study is still important in so far as it spotlights the moral courage of a unique group-special education students and interns. These students require courage and dedication from the outset in order to work with pupils who suffer from learning disabilities, autism, emotional mental disability or physical disabilities, and the stories which emerged from this study might have a good impact on others starting to work in this field. Hillel-Lavian (2013) found that special education students are full of teaching motivation with a wish to change the system. Among their qualities you can find flexibility, commitment, sensitivity and empathy. Since there is no consensus when it comes to courage (Chapa \& Stinger, 2013) we chose to address the term courage based on Kidder's (2005) definition. Therefore we searched their stories for three elements-endurance, standing up for a principle and risk taking. From their stories we tried to extract the characteristics of courage. What drove the students to act, and what risks did they take?

It was found that the two first elements, endurance and sticking to your principles, make the act a courageous one. Without the act, there is no boldness and without a world view and guidelines, the individual will never act. There is an inner conflict between two principles. First, the desire for self-preservation - the egoistic motive to avoid being hurt, damaged or punished. Second, the desire to act for the welfare of others who are weak and lacking a voice-an altruistic motive. The awareness that considered as an act may be followed by negative consequences to the student who is in a subordinate position to an instructor or institution. It could changes the act from one that can be defined as simply brave, to someone who might be called a person with moral courage.

Moral courage in the teaching world means defending your values and it is expressed by statements and actions (Lanchman, 2007): it expresses principles and values. In the students' stories we detected characteristics of boldness such as overriding authority; when students taught topics that did not follow the teacher's instructions or taught them in a more challenging manner, even if it was in disagreement with higher authority. But true moral courage surfaced when information was taken outside the classroom or school to bodies with the ability to act in order to meet the needs of a child being 
harmed.When students were asked what pushed them to act, it was motives of altruism and caring that surfaced. Rate et al. (2007) noted that a brave act is backed up by theories that meet the individual's cognitive structure and his interpretation of the term courage. During their studies, students meet theoretical, educational and philosophical approaches that affect their ideology and their actions. What they say meet the educational theory of caring by Noddings (2003), the philosophy of Le'vinas (1993) and the pedagogy of the oppressed by Freire (1981). All of them call for commitment and responsibility toward the other, for taking action toward the oppressed and for activism.

Finally, the risk and the consciousness of the risk: The students and interns know this act might harm them, so their actions stem from a rational set of values. The cost is both emotional and professional. Most of them described an inner conflict between nonconforming values. Where they identified injustice, mistreatment or harm toward a pupil, they faced a dilemma; to keep quiet or to speak, to do or not to do. Conflicts and dilemmas create stress, distress and fear (Goud, 2005; Kidder, 2005). Fear mostly appears when facing three types of risks - moral, physical and psychological (Pury et al., 2007; Putma, 1997).

The words of the interviewees show they experienced fear and psychological stress. Yet the moral consideration overcame it. They decided to act knowing that it might jeopardize their studies, and harm their reputation, employment prospects and professional future. The study also showed that the students felt confident displaying moral courage since they were backed up and supported by their college, both emotionally and ideologically. This is the reason our study is important to us special education instructors in college. It allows us to see how the initial motivation of special education students, when combined with a philosophical-theoretical approach of caring toward others gained during their studies, give the students strength to perform acts of moral courage.

\section{Study Limitations and Future Research}

The small sample size of this study prevents the findings from being applied universally to all preservice special education students. In addition, the sample does not describe what is happening in different types of classes (inclusive or special) of children with disabilities. However, this article has shed light on an important subject which has been largely ignored, and it would be worthwhile to continue the study using other methodologies.

\section{References}

Aultman, J. (2008). Moral courage through a collective voice. The American Journal of Bioethics, 8(4), 67-69. http://dx.doi.org/10.1080/15265160802147140

Avudi-Dangor, A. (1992). The relationship of burnout to idealistic commitment, social support and self-efficacy among special education teachers. Thesis in partial requirement for M.A. degree in management, Tel-Aviv University (Hebrew).

Baratz, L., Reingold, R., \& Abuatzira, H. (2013). Israeli Teachers' Definitions of Morally Courageous 
Behavior in Education. Journal of Education and Learning, 2(1), 93-84.

Chapa, O., \& Stringer, D. (2013). The path of measuring moral courage in the workplace. SAM Advanced Management Journal, 78(2), 17-24.

Duska, R. (2013). Integrity and Moral Courage. Journal of Financial Service Professionals, 67(1), 20-22.

Freire, P. (1981). Pedagogy of Oppressed. Tel Aviv: Mifrass.

Gavish, B., \& Friedman, Y. (2001). Gaps in perception of the teacher's job and their correlation to the pressures of teaching. In Iyunimbeminhalve' irgunhachinuch (Vol. 24). Haifa: Faculty of Education, University of Haifa, and Israel Teachers Union (Hebrew).

Goud, N. H. (2005). Courage: Its nature and development. Journal of Humanistic Counseling, Education and Development, 44, 102-116.

Graham, B., \& Iannacci, L. (2013). Reconceptualizing "Special Education" curriculum in a Bachelor of Education program: Teacher candidate discourses and teacher education practices. Canadian Journal of Disability Studies, 2, 10-34.

Guba, E., \& Lincoln, Y. (1981). Effective evaluation. San Francisco: Jossey-bass.

Hanline, M. F. (2010). Preservice-teachers' perceptions of field experiences in inclusive preschool settings: Implications for personnel preparation. Teacher Education and Special Education, 53(4), 335-351. http://dx.doi.org/10.1177/0888406409360144

Hillel, L. R. (2008). Motives for Choosing Teaching Special Education Research, Report submitted to the Committee of Research Encouragement. Tel Aviv: Lewinsky College! of Education (Hebrew).

Hillel, L. R. (2013). "You and I will change the world" Student teachers' motives for choosing special education. World Journal of Education. Canada: Sciedu Press.

Iannacci, L., \& Graham, B. (2010). Mind the gap: Destabilizing dominant discourses and beliefs about learning disabilities in a Bachelor of Education program. Alberta Journal of Educational Research, 56(3), 274-290.

Kidder, R. M. (2005). Moral Courage. New York, NY: Harper Collins Publishers.

Klaassen, C. (2007). The moral role of teachers investigated. What did we learn? Paper presented at the 2007 annual convention of the American Educational Research Association. Chicago.

Klaassen, C. (2012). Just a teacher or also a moral example? In D. Alt, \& R. Reingold (Eds.), Changes in teachers' moral role: From passive observers to moral and democratic leaders (pp. 13-30). Rotterdam, the Netherlands: Sense Publishers.

Klaassen, C., \& Maslovaty, N. (2010). Teachers and normative perspectives in education: An introduction. In C. Klaassen, \& N. Maslovaty (Eds.), Moral courage and the normative professionalism of teachers (pp. 1-12). Sense Publishers: Rotterdam.

Lachman, V. D. (2007). Moral courage in action: Case studies. Nursing, 16, 275-277.

Le'vinas, E. (1993). L'ethiquecommephilosophie premiere. J. G. J. Rolland (Eds.), Paris.

McCain, J., \& Salter, M. (2004). Why courage matters. New York: Random House.

Published by SCHOLINK INC. 
Miles, M. B., \& Huberman, A. M. (1994). Qualitative data analysis (2nd ed.). Thousand Oaks, CA: Sage.

Miller, I. (2000). The mystery of courage. Cambridge, MA: Harvard University Press.

Miller, R. (2005). Moral Courage: Definition and Development. Washington DC, Published by the Ethics Resource Center.

Noddings, B. (2003). Caring: A Feminine Approach to Ethics and Moral Education (2nd ed.). Berkeley: University of California Press.

Pury, C., Kuwalski, R. M., \& Spearman, J. (2007). Distinctions between general and personal courage. The Journal of Positive Psychology, 2(2), 99-114.

Putman, D. (1997). Psychological courage. Philosophy, Psychiatry and Psychology, 2, 1-11.

Rate, C. R., Clarke, J. A., Lindsay, D. R., \& Sternber, R. J. (2007). Implicit theories for courage. Journal of positive psychology, 2, 80-98.

Ronen, H. (1988). Normalization as an ideal: On integrating the disabled into society HedHachinuch. Echoes in Education, 60(4), 11-12.

Rorty, A. (1988). Mind in action: Essay on the philosophy of mind. Boston, MA: Beacon Press.

Schechter, M., \& Iram, Y. (2002). Values and educating about values. In N. Masolveti, \& Y. Iram (Eds.), Educating about values in the context of teaching (pp. 11-29). Tel Aviv, Ramot, Israel (in Hebrew).

Shachar, N. (2015). Upwards. Hed Hagan, 3, 50-57.

Shkedi, A. (2010). Multiple Case Narratives: A Qualitative Approach to Studying Multiple Populations. John John Benjamins Publishing Co.

Spektor, M. G. (2010). The story is not the whole story: The narrative identity card. In L. Kasan, \& M. Krumer-Nevo (Eds.), Qualitative investigation data analysis (pp. 63-96). Ben-Gurion University Publishers.

Strauss, A., \& Corbin, J. (1990). Basics of qualitative research: Grounded theory procedures and techniques. Newbury Park, CA: Sage Publications, Inc.

Tangala, M. D., \& Nauta, M. M. (2007). Values, Motivations, and Learning Experiences of Future Professionals: Who Wants to Serve Underserved Populations? Professional Psychology: Research and Practice, 36(6), 688T694.

Tzabar, Ben-Yehosuah, N. (2001). Traditions and Trends in Qualitative Research. Modan Publishers.

Zellermayer, M. (2001). Action research in education: History, characteristics, critics. In N. Tzabar Ben-Yehosuah (Ed.), Traditions and Trends in Qualitative Research (pp. 307-341). Modan Publishers. 